\title{
Value generation using open government data in the public sector: Development and validation of a multidimensional scale
}

\author{
Vanessa Oliveira, ${ }^{1 *}$ Paulo Pinheiro, ${ }^{2}$ Nelson Pinto ${ }^{3}$ \\ $1^{*}$ ORCID Nr: 0000-0002-3228-3899 \\ University of Beira Interior (UBI), Portugal, vanessa.hernandes.oliveira@ubi.pt \\ 2 ORCID Nr: 0000-0002-3228-3899 \\ Research Center in Business Sciences (NECE), University of Beira Interior (UBI), Portugal, pgp@ubi.pt \\ ${ }^{3}$ ORCID Nr: 0000-0002-3228-3899 \\ Federal University of Santa Maria (UFSM), Brazil, nelguimachado@hotmail.com
}

\begin{abstract}
The use of open government data by governments can create opportunities and drive the digital transformation of the public sector. However, there is no integrative measure that assesses the factors that enable public organizations to effectively utilize open government data. The objective of this research was to develop and validate an instrument to assess the factors related to value generation from the use of open government data in the public sector. The construction of the scale was a three-step process. First, the items were structured. Next, a pilot study was performed. Lastly, the instrument was validated. The results indicate that the measure of value generation from the use of open government data is a multidimensional construct, which presents promising implications for future research. This study contributes by developing an instrument that can serve as an analysis tool that will aid public managers who are interested in utilizing open government data.
\end{abstract}

Keywords: Data-driven public sector, open data, absorptive capacity, open government, measurement tool

\section{Introduction}

Open government data (OGD) has become a global brand of open government that has expanded rapidly across several countries, cultures, and political systems (Dawes et al., 2016). Its goal is to promote transparency, provide participatory governance, and unlock social and business value through the consumption of data by different stakeholders (Attard et al., 2016).

In addition to creating, collecting, and publishing data, the public sector is a stakeholder that needs to play the role of data consumer in a manner that enables data to be utilized for the facilitation 
of decision-making in public policymaking, service delivery, organizational management, and innovation (McBride et al., 2019; Sivarajah et al., 2016; Ubaldi, 2020; Van Ooijen et al., 2019). However, the innovative and transformative capacity of OGD needs to be better utilized by the public sector (i.e., value creation through OGD use) so that it can use new knowledge as a differential in relation to other governments and develop/strengthen public trust. This can be achieved through collaboration, which induces governments to go further and place data at the core of thinking about the digital transformation of government (Van Ooijen et al., 2019).

Previous research attempted to explore the public sector's use of OGD to generate value (e.g., Agbozo \& Asamoah, 2019; Maffei et al., 2020; Mergel et al., 2018; Ruijer \& Meijer, 2019). However, there is a dearth of empirical studies on this topic, especially those that identify factors that may influence the public sector's internal use of data. In other words, few studies have sought to identify the factors that allow value to materialize (Jetzek et al., 2014). A possible reason for this may be the lack of an instrument to assess the circumstances that influence the internal use of data by the public sector. Thus, it is necessary to develop a comprehensive and valid scale that can help researchers accurately assess the factors that contribute to the use of OGD in the public sector. Therefore, the research question of this study is: how can the factors that influence value creation from the use of OGD by the public sector be measured? Thus, the aim of this study is to describe the development of, and validate, a measurement instrument for assessing the factors related to the generation of value from the use of OGD by the public sector.

The construction of the scale was based on previous literature on open government and OGD, especially Grimmelikhuijsen \& Feeney (2017) work that assessed the structural, cultural, and environmental characteristics that influence the process of adopting open government in government agencies. The theoretical framework of this study also incorporated the principles of the unified theory of acceptance and use of technology (UTAUT) (Venkatesh et al., 2003), which concerns the individual acceptance of the use of OGD, and absorptive capacity (Zahra \& George, 2002), which relates to the capacity of an organization to acquire, assimilate, transform, and explore new knowledge. This theoretical framework allowed us to identify the multidimensional nature of the key OGD-based value generation construct and capture the domain of influencing factors in the use of OGD by the public sector.

Data from Brazil was collected to validate the developed scale. As a member of the Open Government Partnership, Brazil has implemented numerous open government strategies and initiatives. It recently approved a specific law that provided principles, rules, and instruments for digital government and sought to increase public efficiency, particularly through innovation, digital transformation, citizen participation, and the reduction of bureaucracy (Brasil, 2021).

This research offers significant contributions. First, the development of this scale will increase knowledge about the use of OGD by the public sector. This will enable the identification and analysis of factors that are related to value creation, thereby providing accurate organizational and individual level information, to facilitate the management of public institutions. Second, this study offers a set of core dimensions that capture the uniqueness of the key OGD-based value generation construct. Third, this validated and reliable instrument can serve as an analysis tool that will aid public managers who are interested in utilizing OGD. 
The following section presents the main concepts and definitions that are incorporated into this research. Subsequently, an overview of the methodological approach and a description of the instrument's development and validation process is provided. After that, the results and the discussion are presented. The final section presents the study's conclusion, in addition to its limitations, and suggestions for future research.

\section{Theoretical foundation}

To better understand the idea of value creation from OGD, it previously conducted a review of the literature on open government and OGD, which enabled the identification of potential factors and theoretical models that could be integrated to form the conceptual framework for the generation of value through the use of OGD in the public sector.

Thus, this section first conceptualizes the value of OGD in the context studied. Then, it presents a brief report on some organizational models and factors that influence the adoption of open government and OGD in the public context. Then, it presents the UTAT as an appropriate approach for identifying individual factors. Finally, it describes organizational level absorptive capacity, which is framed as a facilitating factor in OGD-based value generation mechanisms (Jetzek et al., 2013b).

\section{Value generation through OGD by the public sector: conceptualization}

To examine the generation of value through the adoption of OGD by the public sector and the factors that impact it, it is first necessary to clarify the meaning of such value generation. It can be related to the concept of "data-driven public sector" (DDPS), which was presented by the Organization for Economic Cooperation and Development (OECD). Both involve the governmental adoption of data use as a strategic resource, which becomes an integral part of policy formulation, service provision, organizational management, and innovation (Van Ooijen et al., 2019).

The use of OGD can be considered as a form of public sector innovation. According to Damanpour (1991) and Rogers (1995), innovation involves the development and implementation of new ideas or behaviors and the creation of new products/services, new technologies, and administrative structures/systems. Therefore, the use of OGD can be considered as a form of public sector innovation that benefits the economy, society, democracy, and public governance (Agbozo \& Asamoah, 2019; Jetzek et al., 2013a; Zuiderwijk et al., 2015).

For Van Ooijen et al. (2019), the use of data within government can enable anticipatory governance, the design and delivery of policy and services, and performance monitoring and evaluation. Anticipatory governance is the government's ability to anticipate, prepare for, and direct future change; data-driven design and delivery refers to the government's ability to better understand problems, formulate policies, and deliver services that match the needs of its users; and performance monitoring involves the improvement of the government's productivity and the evaluation of policies and their impact (Agbozo \& Asamoah, 2019; Maffei et al., 2020; Van Ooijen et al., 2019). 
These DDPS opportunities are part of one of the twelve principles suggested by the OECD regarding the development and implementation of digital governance strategies that bring governments closer to citizens and businesses (OECD, 2020). Therefore, in this study, these opportunities are considered to be the value generated through the use of OGD by the public sector, as they specify the possible outcomes of the government's incorporation of data into its administrative routines and processes.

\subsection{Research related to the determination of organizational factors that affect the use of open government data}

Organizational factors are the technological, structural, managerial, cultural, and environmental characteristics of an organization that restrict or facilitate the adoption and implementation of new ideas and innovations of all types (Adnan et al., 2019; Damanpour, 1991). A variety of organizational factors have been identified in literature on the adoption of open government and OGD. This research references certain studies that contributed to the identification of potential organizational factors that influence the use of OGD by the public sector.

Grimmelikhuijsen and Feeney (2017) empirically tested an integrative model to understand the determinants of open government adoption in three dimensions: accessibility, transparency, and participation. The authors utilized three consolidated theories as their foundation. These included the diffusion theory of political innovation (Berry \& Berry, 1990), which focuses mainly on the government's decision to adopt a new policy (Guo \& Ba, 2019), and the theory of innovation adoption (Rogers, 1995), which addressed the decision-making process related to the adoption and diffusion of innovation in the organization (Premkumar \& Roberts, 1999). They found that technological capacity, organizational culture, and the political environment are possible determinants in the adoption of resources in open government by local governments in the United States.

Along the same lines, Wang and Lo (2016) presented their theoretical model based on Tornatzky et al.'s (1990) TOE (Technology-Organization-Environment) structure, which describes the process of adoption and implementation of technological innovations at the organizational level. The authors pointed out that perceived benefits, organizational readiness for technology, senior management support, and coercive pressures influenced the adoption of the OGD among government agencies in Taiwan. In another study, Altayar (2018) utilized institutional theory (Scott, 2013) and found that coercive, competitive, and normative pressures led public managers in Saudi Arabia to adopt OGD.

Zhao and Fan's (2018) model was based on resource theory, which outlines how an organization can use its diverse resources to achieve improved results (Barney, 1991). They found that tangible resources (core resources and data) and human resources such as organizational arrangement (managerial support and workforce) and technical capacity (e.g. privacy and data security) impact the adoption of OGD in various government agencies in Shanghai. Utilizing several theoretical models, Yang and $\mathrm{Wu}$ (2016) revealed that sociotechnical determinants such as perceived usefulness, external influence, culture, and organizational capacity shape the intention and behavior of Taiwanese government agencies toward the adoption of OGD. 
Therefore, the surveys reported above are similar, as they are empirical studies that present various theoretical models that assess factors related to institutional, managerial, structural and contextual aspects that shape the adoption of open government and OGD in different contexts. To operationalize the construction of organizational factors, the model by Grimmelikhuijsen and Feeney (2017) was adapted in this study as it addresses the peculiar characteristics of open government, such as transparency and participation. In this study, organizational factors were framed in three dimensions: technological, cultural, and environmental.

\subsection{Research related to the determination of individual factors that affect the use of open government data}

Individual factors are related to the characteristics of individuals. It is known that competence, knowledge, experience, and the availability of human capital play a fundamental role in the adoption of technology for open government initiatives (Adnan et al., 2019; Van Ooijen et al., 2019). The main features of the UTAUT were used as the individual factors in this study. Although some studies have validated the model of acceptance and use in OGD, few have posited determinants of behavioral intent as individual factors in the use of OGD in the public sector.

The UTAUT was developed by Venkatesh et al. (2003), who devised a model based on eight theories (Theory of Reasoned Action -TRA; Technology Acceptance Model - TAM; Motivational Model - MM; Theory of Planned Behavior - TPB; Combined TAM and TPB - C-TAMTPB; Model of Personal Computer Utilization - MPCU; Innovation Diffusion Theory - IDT; and Social Cognitive Theory SCT) to identify which determinants influence the adoption and use of information technology by users in the organizational context.

The UTAUT highlighted four determinants of technology acceptance and use: performance expectation, effort expectation, social influence, and facilitating conditions (Venkatesh et al., 2003). Performance expectation refers to the individual's belief that the use of technology can help improve their performance at work. The expectation of effort, on the other hand, is the level of ease that can be associated with the use of technology. Social influence refers to how other people's opinions influence the use of technology. Finally, facilitating conditions refer to the "degree to which an individual believes there is an organizational and technical infrastructure to support the use of technology" (Venkatesh et al., 2003, p.453).

The original model by Venkatesh et al. (2003) consisted of three main constructs that are direct determinants of behavioral intention: performance expectation, effort expectation, and social influence. Additionally, it contained two constructs that directly predict the use of information technology: enabling conditions and behavioral intent. These specific characteristics enabled the model to be widely used in research on user behavior intent with regard to technology adoption (Williams et al., 2015). Furthermore, it is considered a useful tool for managers because it provides important information that enables us to understand the factors that motivate the acceptance of new technologies in organizations. Consequently, it facilitates the incorporation of features that can influence employees to adopt and use new systems (Venkatesh et al., 2003). Additionally, it can help organizational managers to establish activities that effectively shape individuals' attitudes (Dwivedi et al., 2019). 
Given the importance of this theory within the organizational context, this research operationalized the construct of individual factors in three dimensions to measure the behavioral intention of OGS use. This multidimensional construct encompassed performance expectation, effort expectation, and social influence.

\subsection{Research related to the determination of facilitating factors that affect the use of open government data}

An organization's absorptive capacity is viewed as an essential facilitating factor because it enables the organization to go beyond its limits to obtain data, information, or knowledge and thus productively use these external resources to generate value (Jetzek et al., 2013a). According to Huber et al. (2020), organizations that intend to use data need to develop their absorptive capacity to facilitate innovation. Given that there is limited research absorptive capacity in the public context and on the use of OGD, the absorptive capacity theory was utilized in this study.

Absorptive capacity theory was introduced by Cohen and Levinthal (1990) to explain how and why an organization develops the capacity to explore, recognize the value of, and assimilate new knowledge. This theory studied the capabilities of organizations to innovate with knowledge inserted in internal and external environments (Todorova \& Durisin, 2007). For this, organizations depend on the diversity of knowledge among individuals; prior knowledge, which must be closely related to external knowledge to facilitate assimilation; and the creative and effective use of new knowledge (Cohen \& Levinthal, 1990).

Many reconceptualizations emerged in an attempt to improve this theory (e.g., Lane et al., 2006; Lewin et al., 2011; Todorova \& Durisin, 2005, 2007; Zahra \& George, 2002). According to (Murray et al. (2011), the definition that best fits the context of the public sector is the one provided by Zahra \& George (2002), who viewed absorptive capacity dynamically. They defined absorptive capacity as a set of organizational routines and processes in which organizations acquire, assimilate, transform, and explore knowledge (Zahra \& George, 2002). These capabilities were defined as potential absorptive capacity and relative absorptive capacity, each of which has a distinct but complementary function with regard to value creation.

Potential absorptive capacity consists of knowledge acquisition and assimilation resources (Zahra \& George, 2002). Here, acquisition refers to an organization's ability to recognize, identify, and obtain knowledge from external sources (Flatten et al., 2011). On the other hand, assimilation refers to the routines and processes that allow the organization to analyze, interpret, and understand the external knowledge acquired (Szulanski, 1996; Zahra \& George, 2002). These capabilities play an important role in renewing the knowledge base, ensuring strategic flexibility to alter and reconfigure organizational operations, and securing the skills needed to compete in changing markets (Zahra \& George, 2002).

Realized absorptive capacity includes transformation and exploration, which are the capacities to explore the knowledge absorbed and to obtain some kind of gain from it (Flatten et al., 2011). Transformation denotes the organization's ability to develop and refine routines that facilitate the assimilation of existing knowledge with newly acquired knowledge for future use (Todorova \& 
Durisin, 2007). Exploitation is the ability of an organization to improve, expand, and use its existing routines, skills, and technologies to create something new through the integration of acquired and transformed knowledge (del Carmen Haro-Domínguez et al., 2007; Zahra \& George, 2002). Explorative resources can be used to convert knowledge into new products to improve the performance, competitive advantage, and productivity of organizations (del Carmen Haro-Domínguez et al., 2007).

Therefore, the potential and realized absorptive capacity have peculiarities that allow them to be developed and used separately. However, they must exist simultaneously to achieve better organizational results (Zahra \& George, 2002). These dimensions complement each other to transform the organization's absorptive capacity into a coherent dynamic capacity that promotes change, organizational evolution, and value creation through innovation (Zahra \& George, 2002). Thus, absorptive capacity, which is considered a multidimensional construct, was operationalized as a one-dimensional construct in this study. In other words, the set of two dimensions was unified into a single dimension.

\subsection{Structure of the proposed multidimensional scale}

The structure of the multidimensional scale consists of multifaceted and interdependent factors that influence and drive the generation of value from the use of OGD in the public sector. These specific factors were categorized into three dimensions: organizational factors, individual factors and facilitating factors. Table 1 summarizes these main dimensions of value creation, which were comprehensively addressed in the previous sections.

Table 1. Multidimensional scale structure

\begin{tabular}{|l|l|l|}
\hline Dimensions & Finality & Theoretical basis \\
\hline Organizational factors & $\begin{array}{l}\text { Measure the degree of technological, } \\
\text { cultural, and environmental pres- } \\
\text { sures that an organization faces with } \\
\text { regard to the use of OGD. }\end{array}$ & $\begin{array}{l}\text { Grimmelikhuijsen and } \\
\text { Feeney (2017) }\end{array}$ \\
\hline Invironmental & $\begin{array}{l}\text { Measure the perception and motiva- } \\
\text { tion that public servants have about } \\
\text { the use of OGD. }\end{array}$ & Venkatesh et al. (2003) \\
$\begin{array}{l}\text { Performance expectation } \\
\text { Sffort expectation }\end{array}$ & $\begin{array}{l}\text { Measure the degree to which a public } \\
\text { organization acquires, assimilates, } \\
\text { transforms, and exploits knowledge } \\
\text { arising from OGD. }\end{array}$ & $\begin{array}{l}\text { Zahra and George } \\
\text { (2002) }\end{array}$ \\
\hline $\begin{array}{l}\text { Facilitating factors } \\
\text { Absorptive capacity }\end{array}$ & $\begin{array}{l}\text { Value generation from the use of OGD } \\
\text { public organization uses OGD as a basis to support anticipatory }\end{array}$ \\
$\begin{array}{l}\text { It is the degree to which a } \\
\text { governance, design and delivery, and performance monitoring. }\end{array}$ \\
\hline
\end{tabular}




\section{Methodology}

In order to develop and validate the multidimensional scale, MacKenzie et al.'s (2011) proposed guidelines and procedures were adopted. The construction of the scale was divided into three steps (Figure 2). First, the items were developed and validated through content validation. Second, the first round of data collection (pilot test) was conducted in order to purify the items. To this end, a reliability test, which resulted in the exclusion of some items, was performed. Third, the second round of data collection (instrument application) was conducted to test, purify, and validate the scale structure. This included a reliability test, an exploratory factor analysis, confirmatory composite analysis, and convergent and discriminant validation.

Figure 2. Scale flowchart

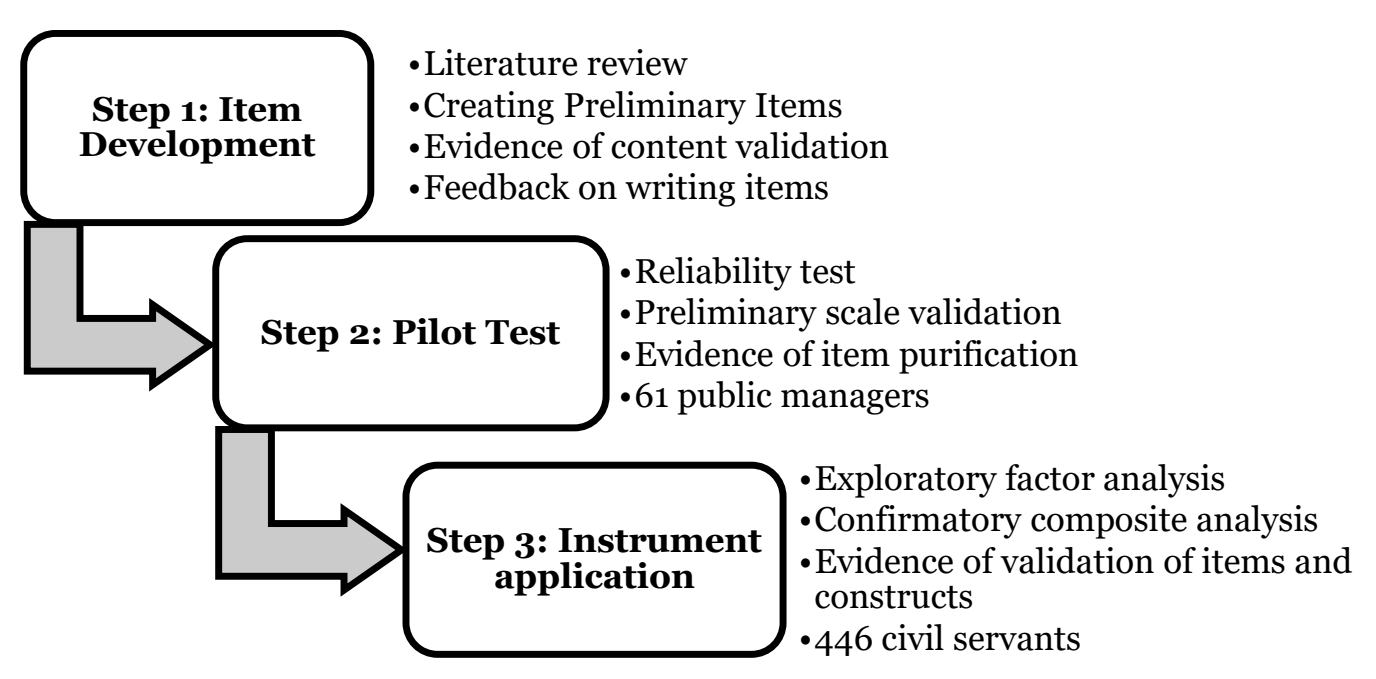

\subsection{Item development}

Based on the preliminary literature review, organizational factors, individual factors, and facilitating factors (absorptive capacity) were identified as factors that influenced the generation of value related to the use of OGD by the public sector. As there is no single scale that enables the evaluation of the generation of value, items from other scales were adopted, which resulted in the formation of subscales. All subscales were measured by latent variables with multiple reflective items since the items are influenced by latent variables (Hair et al., 2020). The organizational and individual factors subscales were operationalized with subsets of items that were adapted to measure the specific dimensions of each construct.

The items belonging to the organizational factors construct were divided into three subsets: technological factors, which refer to the technological infrastructure and technical capacity that enable 
the public organization to use OGD; cultural factors, which indicate whether public organizations are receptive to innovation and civic participation (Grimmelikhuijsen \& Feeney, 2017); and environmental factors, which are internal and external pressures (Dimaggio \& Powell, 1983) exerted on public organizations to use OGD. The set of items were adapted from the literature on adoption determinants (e.g., Grimmelikhuijsen \& Feeney, 2017; Wang \& Lo, 2016). Some structural modifications were made to make them more relevant to the context of OGD use.

The items belonging the individual factors construct were distributed into three subsets, which measured effort expectation, performance expectation, and social influence. All subsets permit the assessment of an individual's perception and behavioral intention with regard to the adoption and use of OGD within the organization. Items related to individual factors were based on the questions proposed by Venkatesh et al. (2003) and Zuiderwijk et al. (2015). These questions underwent semantic changes to suit the context of the study.

The items belonging to the absorptive capacity construct were drawn from the scale developed and validated by Flatten et al. (2011). Semantic changes were made to the questions to adapt them to the study. In some cases, the word "company" was replaced with "institution." Thus, questions such as "In our company, ideas and concepts are communicated between departments" were altered to "In our institution, ideas and concepts are communicated between departments."

The items of the value generation construct represented the possible opportunities that could drive the adoption and use of OGD within the public sector. For its operationalization, the items that measured aspects related to anticipatory governance, design, and delivery, management, and performance were adopted from Van Ooijen et al.'s (2019) study.

All adapted items were initially translated from English into Portuguese, which was followed by a back translation from Portuguese into English. The translated questions were sent to the translators to verify their accuracy. All items were measured on a seven-point Likert scale, which ranged from 1 (strongly disagree) to 7 (strongly agree). According to Finstad (2010), seven-point Likert items are more appropriate for electronically-distributed questionnaires and provide a more accurate measure of a participant's true evaluation. The seven-point scale provides more options, consequently increasing the probability of reflecting the objective reality of people (Joshi et al., 2015). Demographic variables were also included in the questionnaire.

At this stage, a content validation was performed on the initial items by a panel of three experts. This validation aimed to verify whether each individual item captured an aspect of the construct domain and whether a set of items collectively represented the entire content domain of the construct (Ali et al., 2014; MacKenzie et al., 2011). The experts assessed the context of the study and the ambiguity, relevance, and superfluity of the questions. This resulted in the elimination and reformulation of some items. Appendix presents an overview of the items.

\subsection{Pilot test}

The pilot test was the first round of data collection that served to improve and refine the items. It functioned as a pre-evaluation of the scale. The printed surveys were distributed to public managers 
who participated in the 4th National Forum of Deans of Planning and Administration of Federal Institutions of Higher Education from October 21 to 24, 2019. Public managers were targeted owing to their familiarity with and knowledge regarding the subject under study. Additionally, they represent senior-level leadership, whose support is crucial to the adoption of open government initiatives (Lee \& Kwak, 2012). Participants were instructed to complete the face-to-face questionnaire and provide comments and suggestions while completing the survey on how to further improve the measurement instrument.

A total of 87 questionnaires were distributed. Only 61 valid responses were obtained, representing a response rate of $80.59 \%$. The sample consisted of 39 male managers (63.90\%) and 22 female managers $(36.10 \%)$. In total, 19 respondents $(31.10 \%)$ were between 31 and 40 years of age, 15 (34.60\%) were between 41 and 50 years of age, 17 (27.90\%) were between 51 and 60 years of age, and $10(16.40 \%)$ were over 60 years of age. Most respondents $(31 ; 50.8 \%)$ had served in public institutions for between 5 and 15 years. Additionally, 24 (38.30\%) respondents had more than 20 years of public service experience, 5 (to $8.0 \%$ ) had between 15 and 20 years of experience, and only 1 (1.60\%) respondent had less than 5 years of public service experience.

Based on the comments and suggestions received, we revised the instrument, assessing and improving the understandability of the items. In addition, a reliability test was performed, which resulted in the removal of the items that presented a poor performance in capturing the construct that motivated the measure (Churchill, 1979). The initial version of the scale was thus developed with a total of 55 items. This version is presented in Appendix.

\subsection{Instrument application}

At this stage, the second round of data collection was carried out to expand the sample and produce empirical results to assess the validity of the measurement instrument. The target population was federal civil servants in Brazil's executive branch, as they are potential users of data within the government (Ruijer \& Meijer, 2019). The Brazilian government was chosen as the research sample due to the country's commitment toward the implementation of open government initiatives. Brazil has been striving to establish a new idea of public administration that is open to public scrutiny, as is reflected by the country's rank in the Global Open Data Index in 2016 (8th) and Open Data Barometer - Leaders Edition in 2017 (18th). Brazil is also a co-founder of the Open Government Partnership (OGP) initiative, and is one of the countries that offers courses on the use of digital tools within public organizations to its employees (Ubaldi, 2020). Therefore, it is interesting to study this context from another perspective, which differs from the current government that produces and owns data for a future government that is a potential user of OGD.

Data collection took place through an online system created by the federal government, known as the Integrated Platform for Ombudsman and Access to Information (Brasil, 2020) (https://falabr.cgu.gov.br/). A registration was performed to access the system. From this, it was possible to send a request for collaboration to each of the Organisation's federal agencies of public administration. There was a summary of the survey with a link to the questionnaire and a request to disseminate the questionnaire among the institution's servers. In other words, the person responsible for the service channel was asked to share the investigation instrument with all public servants 
at his institution, especially those directly or indirectly involved with the use of OGD. The questionnaire was available for five months during the year 2020. At the end of this period, 446 participants were obtained who structured the final sample. The description of this sample is found in Table 1.

Table 2: Sample profile $(\mathrm{N}=446)$

\begin{tabular}{|c|c|c|c|}
\hline \multicolumn{2}{|l|}{ Descriptions } & \multirow{2}{*}{$\begin{array}{l}\text { Frequency } \\
268\end{array}$} & \multirow{2}{*}{$\begin{array}{l}\text { Percentage (\%) } \\
60.1\end{array}$} \\
\hline Gender & Male & & \\
\hline & Female & 178 & 39.9 \\
\hline \multirow[t]{5}{*}{ Age } & Up to 30 years & 23 & 5.2 \\
\hline & 31 to 40 years & 156 & 35.0 \\
\hline & 41 to 50 years & 133 & 29.8 \\
\hline & 51 to 60 years & 98 & 22.0 \\
\hline & Over 60 years & 36 & 8.1 \\
\hline \multirow[t]{4}{*}{ Years of public service } & Less than 5 years & 28 & 6.3 \\
\hline & From 5 to 15 years & 235 & 52.7 \\
\hline & From 15 to 20 years & 65 & 14.6 \\
\hline & More than 20 years & 118 & 6.5 \\
\hline \multirow[t]{2}{*}{ Leadership role } & Yes & 257 & 57.6 \\
\hline & No & 189 & 42.4 \\
\hline \multirow[t]{2}{*}{ OGD use } & Yes & 347 & 77.8 \\
\hline & No & 99 & 22.2 \\
\hline
\end{tabular}

\subsection{Data analysis}

Before performing the data analysis to assess the psychometric properties and quality of the set of items, the answers to the items were organized, coded, and tabulated using SPSS (Statistical Package for the Social Sciences) version 27. Then, descriptive statistics were carried out to observe the type of sample. An internal consistency analysis was then conducted to demonstrate the reliability of the observed values.

Then, an exploratory factor analysis (EFA) was conducted with an oblique rotation principal component extraction method (factors related to each other) to verify the interrelationships between the items (scale dimensionality), refine them, and eliminate those that could compromise the results of the analyses (Floyd \& Widaman, 1995; Hair et al., 2009). To determine the number of factors, the Kaiser decision criterion was applied, verifying the scree plots test. There are no hard guidelines with regard to assessed commonality, which refers to the estimation of the shared variance of a 
variable, but the acceptable minimum is above 0.600 for most variables (Hair et al., 2009; Hinkin, 1998). The factor loading, which indicates the simple correlation of items with their latent variables, was considered to exceed 0.300 . Thus, it met the minimum level for interpretation of structure and significance (Hair et al., 2009). Items with cross load (a high load on two or more factors) were eliminated (Hair et al., 2009).

To assess and confirm the measurement properties of the set of items and constructs, a confirmatory composite analysis (CCA) was performed (Hair et al., 2020) using the SmartPLS 3.0.M3 software, which uses the least squares technique (Partial Leats Square-PLS-SEM). The PLS-SEM stands out in a small sample and a more complex measurement model with many latent items and variables (Akter et al., 2017), in exploratory research where the theory is less developed (Hair et al., 2011), and in the development of scale, as it makes it possible to assess the reliability, convergent validity, and discriminant validity of measurements according to the criteria associated with the specification of the reflective measurement model (Hair et al., 2009). The convergent validity was demonstrated by assessing the degree of association between the measurement item and its assumed theoretical construct (Gefen \& Straub, 2005; MacKenzie et al., 2011). Ascertaining the discriminant validity involved examining the degree to which two similar concepts were distinct (Hair et al., 2009, p.126).

\section{Results}

Table 3 presents the results of the descriptive analysis of the sample and the internal consistency of each construct. The means of the variables ranged from 4.107 to 5.598 and their standard deviations ranged from 0.960 to 1.444 . The mean of the responses related to the performance expectation variable proved to be the only one to be closer to the extreme values related to agreement, whereas the means of the other variables were closer to impartiality (I neither agree nor disagree). The internal consistencies of the constructs evaluated with Cronbach's alpha reached values above 0.800 , indicating that the reliability of the answers was between "good" and "very good" (Pestana \& Gageiro, 2008). In general, the initial scale showed an excellent level of internal consistency $(\alpha=0.965)$.

Table 3: Descriptive statistics and internal consistency

\begin{tabular}{|l|l|l|l|l|l|l|}
\hline Constructs/latent variables & N & Min. & Max. & Mean & SD & $\begin{array}{l}\text { Cronbach's } \\
\text { Alpha }\end{array}$ \\
\hline Organizational Factors (ORF) & 446 & 1 & 7 & 4.295 & 0.960 & \\
\hline Environmental (EN) & 446 & 1 & 7 & 4.589 & 1.357 & \\
\hline Cultural (CU) & 446 & 1 & 7 & 4.971 & 1.339 & \\
\hline Technological (TE) & & & & & 0.893 \\
\hline Individual Factors (INF) & 446 & 1 & 7 & 5.598 & 1.351 & \\
\hline Performance Expectation (PE) & 44639 & 1.278 & \\
\hline Expectation of Effort (EE) & 446 & 1 & 7 & 4.931 & \\
\hline
\end{tabular}




\begin{tabular}{|l|l|l|l|l|l|l|}
\hline Social Influence (SI) & 446 & 1 & 7 & 4.312 & 1.529 & \\
\hline Facilitating Factor (FFA) & 446 & 1 & 7 & 4.833 & 1.169 & \\
\hline Absorptive Capacity (ACAP) & 446.940 \\
\hline Value Generation (VGE) & $\mathbf{4 4 6}$ & $\mathbf{1}$ & & $\mathbf{4 . 1 0 7}$ & $\mathbf{1 . 4 4 4}$ & \\
\hline Value Generation &
\end{tabular}

Note: Min: Minimum; Max: Maximum; SD: Standard deviation

Before performing the dimensionality analysis, the adequacy of the sample for EFA was assessed using the Kaiser-Meyer-Olkinmeasures (KMO) and Bartlett's test of sphericity. We found a $\mathrm{KMO}=0.945$ and $\mathrm{x}^{2}=18838.080, \mathrm{df}=1128, \mathrm{p}=0.000$, indicating that they were significant $(\mathrm{p}<0.001)$. In other words, there were sufficient correlations between the original variables (Hair et al., 2009). Therefore, the two suitability procedures showed that the sample met the criteria to proceed with the EFA.

The initial factor analysis extracted ten factors whose eigenvalues were $\geq 1$ (Kaiser, 1960), which explained approximately $71.915 \%$ of the variability of the initial variables. Items with factor loadings less than 0.300 (Hair et al., 2009) and those with more than two factors (cross-loading) were eliminated. Several simulations were performed to establish which items would be excluded. This resulted in the elimination of the seven items (AM_1; AM_3; AM_5; AM_9: CPA_1; CPA_3; CPA_10) after ten iterations. For example, item AM_9, entitled "There is internal pressure on the part of public servants who adopt open government data in their professional area" was excluded for having high factor loadings in more than one factor. This meant that this item was strongly associated with other concepts (constructs) and did not represent a single construct. The reason for this may have been the similarity of its semantic content with other items.

The remaining 47 items were loaded in their corresponding factors, as can be seen in Table 4 . The subscales' reliabilities ranged from 0.801 to 0.964 . Therefore, all of them were above the recommended limit of 0.700 (Nunnally, 1978). The eight factors accounted for $71.147 \%$ of the variance.

Table 4: Dimensionality analysis

\begin{tabular}{|l|l|l|l|l|l|l|l|l|l|}
\hline Items & $\begin{array}{l}\text { Cronbach's } \\
\text { Alpha }\end{array}$ & F1 & F 2 & F3 & F 4 & F 5 & F 6 & F 7 & F 8 \\
\hline VGE_11 & 0.964 & 0.890 & & & & & & & \\
\hline VGE_5 & & 0.868 & & & & & & & \\
\hline VGE_2 & & 0.856 & & & & & & & \\
\hline VGE_3 & & 0.855 & & & & & & & \\
\hline VGE_12 & & 0.854 & & & & & & & \\
\hline
\end{tabular}




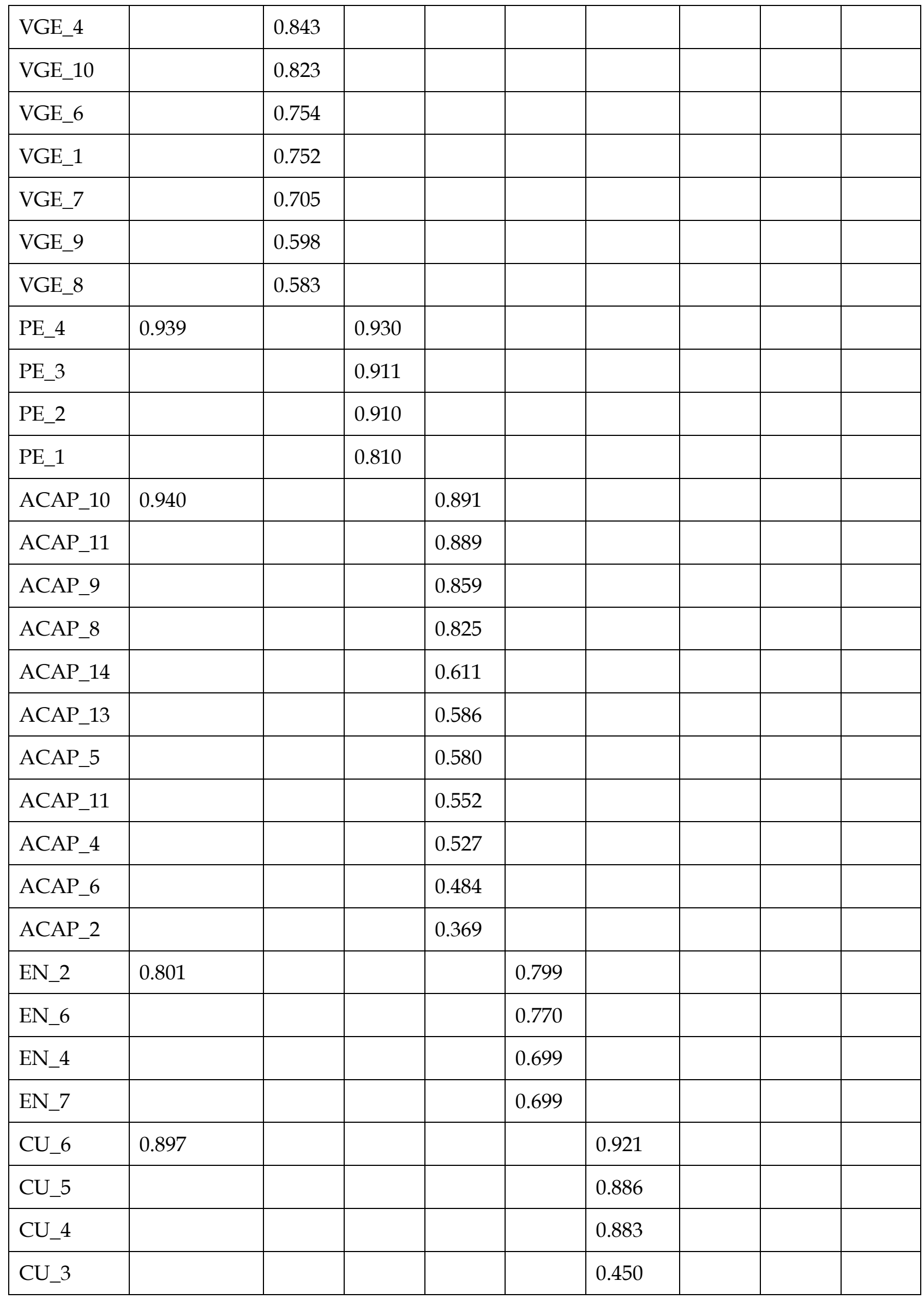




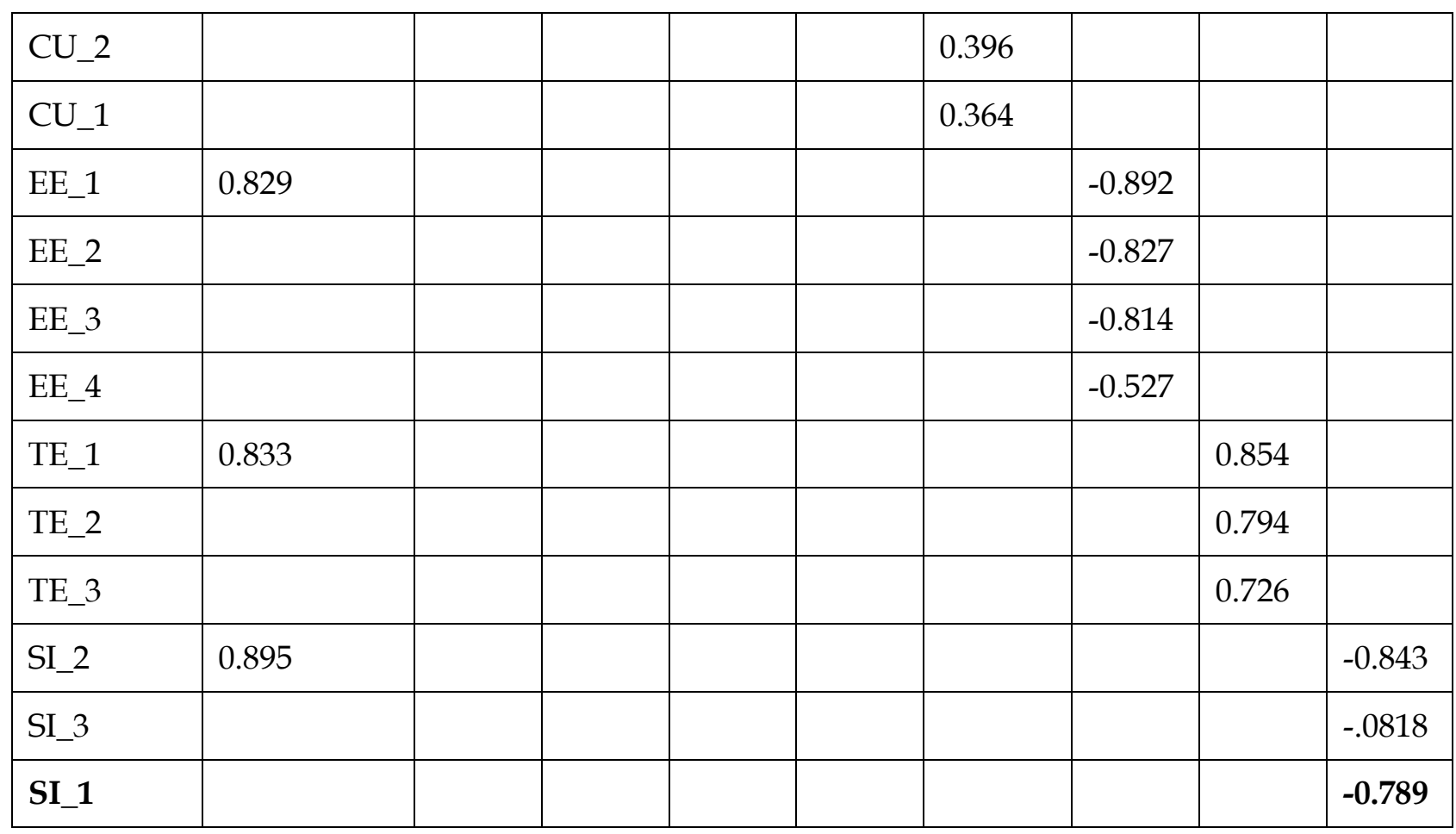

The first factor appeared to be the most important, as it explained much of the variability of the original data (38.718\%). This factor had 12 items that refer to the possibilities that the use of OGD by the public sector can provide. The first three items with the highest loads were: "Our organization analyzes the OGD to identify the effects of a decision, policy, or action and makes necessary adjustments"; "Our managers use OGD to support the debate process with stakeholders, providing detailed information about a political problem in an accessible way"; and "Our organization uses OGD and trends to try to predict the results of our management actions" (see Appendix A). These items focused on the use of OGD data to improve government, understand problems, and prepare for future actions. Therefore, this subscale measured the generation of value through the use of this data.

The second factor, performance expectation, explained $9.668 \%$ of the variability of the original data. The four items measured whether public servants perceive the use of OGD in their professional activities to be advantageous. This is evidenced in the three heavily loaded items in the factor, which were "The use of OGD improves my performance at work"; "Using OGD will increase my productivity"; and "The use of OGD will be useful in my daily activities at work."

The third factor, absorptive capacity, corresponded to $5.196 \%$ of the variance. Overall, 11 items measured the internal capacities of public organizations to acquire, assimilate, transform, and explore knowledge extracted through the use of data. The items with the strongest loading emphasized the ability of public servants to apply the acquired knowledge. These were: "Our servants associate existing knowledge with new solutions"; "Our servants are able to apply new knowledge in their practical work"; and "Our servers are trained to absorb new knowledge, use it for another purpose, and make it available. " 
The fourth factor was responsible for $4.633 \%$ of the variance and consisted of four items that shape the environmental context in which public organizations are inserted. This factor is demarcated by three items: "Most public organizations adopt OGD in their procedures"; "The OGD have been widely adopted by public bodies"; and "Higher-level public agencies place a lot of emphasis on adopting OGD. "These items expressed how public organizations view their peers and the persuasion of the internal use of OGD.

The fifth factor explained $3.897 \%$ of the data variance and corresponded to cultural factors. This factor loaded six items that measure the existence of a favorable organizational climate for the adoption of innovative practices, especially concerning open government initiatives such as civic participation. The first items illustrate this trend: "Our organization believes that it is the responsibility of the public administration to encourage citizens to participate in the deliberation and decision-making processes"; "Our organization believes that citizen participation really increases the effectiveness of public administration"; and "Our organization believes that citizen participation, especially in deliberative and decision-making processes, is necessary."

The sixth factor, effort expectation, explained $3.484 \%$ of the variance. The four grouped items verified whether use OGD is an easy task for public servants. This can be seen in the main items: "I can easily develop skills to use OGD"; "Learning to use open OGD will be easy for me"; and "I fully understand how to use open government data."

The seventh factor explained $3.100 \%$ of the variance, and its three items referred to the technical and technological infrastructure of the public organizations regarding the use of OGD. These items were: "Our organization is well equipped to manage important security and privacy issues related to the adoption of OGD"; "Our organization has adopted clear data security policies to ensure citizen privacy"; and "Our information technology people have knowledge, skills, and experience."

The last factor, social influence, explained $2.454 \%$ of the variance, and its three items explored whether the opinion of other people influenced the behavior of public servants with regard to the use of OGD. These items include: "People who matter to me think I should use OGD"; "People whose opinions I value encourage the use of OGD"; and "People who influence my professional behavior think I should use OGD."

After the EFA, a CCA was performed to verify the reliability and validity of the measures. Three criteria were used for convergent validation (Hair et al., 2020): estimates and significance of loads of each item, composite reliability (CC) for latent variables (constructs), and average variance extracted (AVE).

All the item loads were significant and ranged from 0.705 to 0.960 , indicating that the reliability of reflective items was acceptable. Most loads were above 0.708 , implying that more than $50 \%$ of the item's variance was explained by the latent variable (Hair et al., 2020). CC and AVE are two metrics that indicate the validation of the construct (latent variable). The former assesses the internal consistency of the latent variable, whereas the latter examines the mean variance between the latent variable and its items (Hair et al., 2020). The results indicated that the latent variables displayed a high reliability $(>0.70)$. The VEM for the latent variables ranged from 0.628 to 0.827 , which exceeded 
the cutoff point of 0.50 (Fornell \& Larcker, 1981). All results related to convergent validity are shown in Table 5.

Table 5: Convergent validity

\begin{tabular}{|c|c|c|c|c|}
\hline Constructs & Latent variables/items & Standardized load & $C C(\geq 0,7)$ & $\operatorname{AVE}(\geq 0,5)$ \\
\hline \multirow[t]{16}{*}{ ORF } & \multicolumn{2}{|l|}{ Environmental } & 0,872 & 0,631 \\
\hline & EN_2 & 0,804 & & \\
\hline & EN_4 & 0,731 & & \\
\hline & EN_6 & 0,854 & & \\
\hline & EN_7 & 0,782 & & \\
\hline & \multicolumn{2}{|l|}{ Cultural } & 0,922 & 0,664 \\
\hline & CU_1 & 0,763 & & \\
\hline & CU_2 & 0,765 & & \\
\hline & CU_3 & 0,798 & & \\
\hline & CU_4 & 0,830 & & \\
\hline & CU_5 & 0,871 & & \\
\hline & CU_6 & 0,854 & & \\
\hline & \multicolumn{2}{|l|}{ Technological } & 0,900 & 0,751 \\
\hline & TE_1 & 0,891 & & \\
\hline & TE_2 & 0,889 & & \\
\hline & TE_3 & 0,818 & & \\
\hline \multirow[t]{10}{*}{ INF } & \multicolumn{2}{|l|}{ Performance expectation } & 0,957 & 0,846 \\
\hline & PE_1 & 0,869 & & \\
\hline & PE_2 & 0,935 & & \\
\hline & PE_3 & 0,937 & & \\
\hline & PE_4 & 0,937 & & \\
\hline & \multicolumn{2}{|l|}{ Effort expectation } & 0,888 & 0,664 \\
\hline & EE_1 & 0,795 & & \\
\hline & EE_2 & 0,812 & & \\
\hline & EE_3 & 0,858 & & \\
\hline & EE_4 & 0,794 & & \\
\hline
\end{tabular}




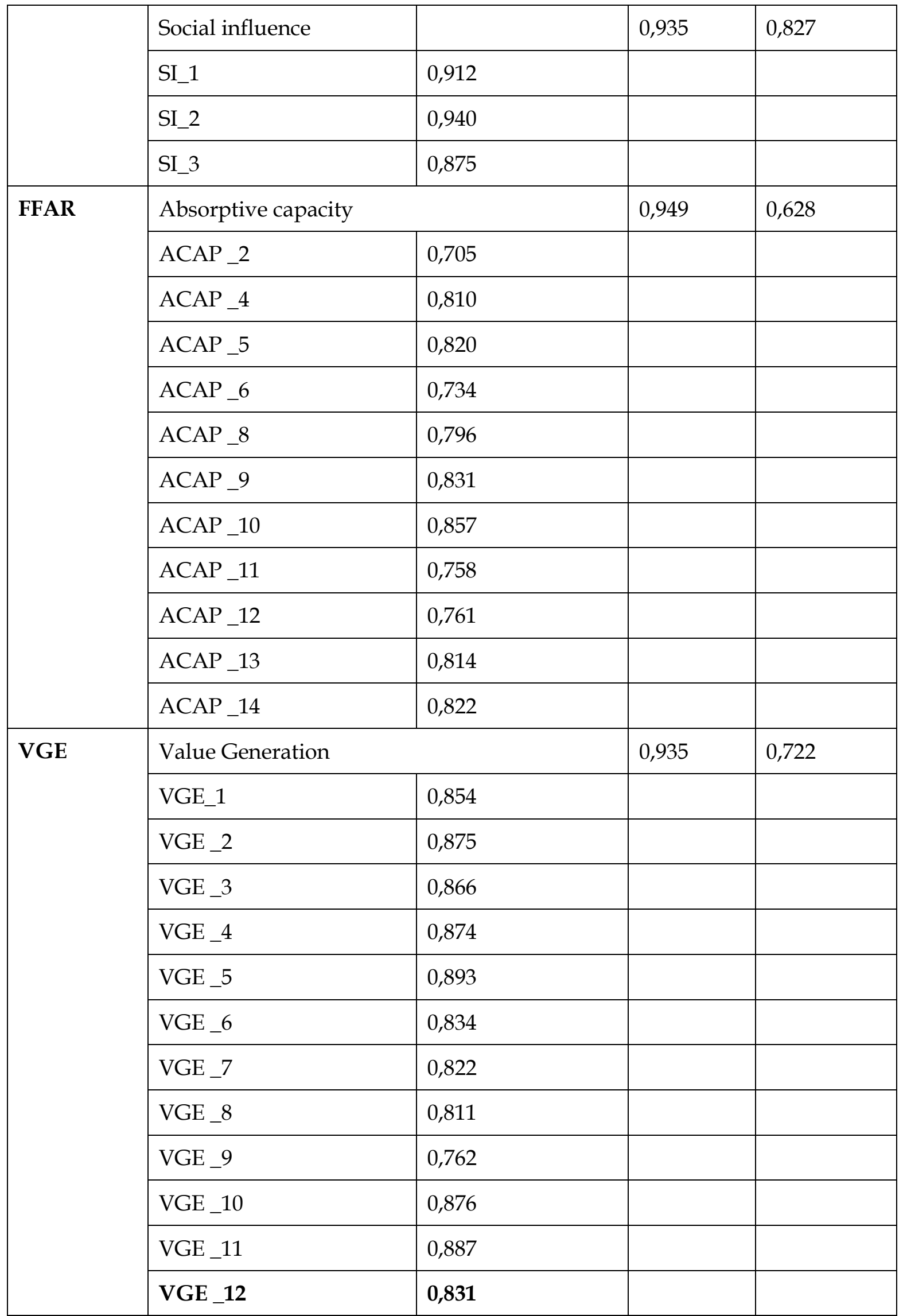

Note: CC: Composite Reliability; AVE: Average Variance Extracted 
Two criteria were used to investigate the discriminant validity: the Fornell-Larcker criterion and the Heterotrait-Monotrait (HTMT) correlation ratio (see Table 6). The first criterion establishes that the diagonal value of the square root of the AVE of each latent variable must be greater than the estimates of the squared correlations with the other latent variables (Hair et al., 2019). The HTMT correlation ratio aims to quantify the similarity between constructs (or latent variables), which should generally be less than one (Henseler et al., 2015). However, the literature has defined some cutoff values such as 0.85 and 0.90 to interpret the HTMT results (Hair et al., 2020).

Table 6: Discriminant validity

\begin{tabular}{|l|l|l|l|l|l|l|l|l|}
\hline Constructs/ latent variables & EN & CU & TE & PE & EE & SI & ACAP & VGE \\
\hline EN & $0.794^{*}$ & 0.466 & 0.369 & 0.195 & 0.380 & 0.403 & 0.457 & 0.503 \\
\hline CU & 0.397 & $0.814^{*}$ & 0.601 & 0.225 & 0.280 & 0.418 & 0.739 & 0.700 \\
\hline TE & 0.304 & 0.520 & $0.867^{*}$ & 0.141 & 0.261 & 0.253 & 0.608 & 0.579 \\
\hline PE & 0.168 & 0.207 & 0.122 & $0.920^{*}$ & 0.428 & 0.552 & 0.170 & 0.258 \\
\hline EE & 0.312 & 0.247 & 0.218 & 0.395 & $0.815^{*}$ & 0.529 & 0.274 & 0.283 \\
\hline SI & 0.341 & 0.374 & 0.217 & 0.508 & 0.472 & $0.909^{*}$ & 0.370 & 0.486 \\
\hline ACAP & 0.401 & 0.681 & 0.539 & 0.158 & 0.246 & 0.340 & $0.793^{*}$ & 0.755 \\
\hline VGE & 0.446 & 0.652 & 0.519 & 0.246 & 0.263 & 0.471 & 0.724 & $0.849^{*}$ \\
\hline
\end{tabular}

Note 1: *Diagonal values are the square root of AVE; values below the diagonal are the squared correlations; values above the diagonal are HTMT.

The results indicated that the discriminant validity was met in both criteria, as the diagonal values of the correlations are higher and the HTMT values were below the recommended value. Therefore, the constructs (or latent variables) are statistically different

\section{Discussion and Implications for Practice}

This article aimed to develop and validate a tool that enables the measurement of the factors involved in generating value from the use of OGD. Data can take on different roles and favor the digital transformation of the public sector (Duan et al., 2020; Gao \& Yu, 2020; Maffei et al., 2020; Ubaldi, 2020; Van Ooijen et al., 2019). This study contributes in several ways to the existing open government and OGD adoption literature and provides practical implications for public managers.

First, a scale was constructed using the set of procedures proposed by MacKenzie et al., (2011), which involved item development, purification, and validation. The proposed scale presented reliable and valid psychometric properties. The AFE and CCA results confirmed that the generation of value from the use of OGD is a multidimensional construct. Each of these distinct dimensions measures specific characteristics. Additionally, the multiple measures are in line with their respective dimensions, revealing a perfect understanding of what is being evaluated. 
Second, this construction-to-scale study theoretically advanced the concept of OGD-based value generation. During the development of this multidimensional scale, this study determined the measure of value generation from the use of OGD. The use of OGD favors governments in areas related to anticipatory governance, the provision of public services that fulfill societal needs, and the evaluation of results with a focus on continuous improvement. This study differed from the work of Jetzek et al. (2013a), who interpreted value creation as the use of OGD only for economic and social purposes and provided a measure to capture value creation at the business level. Instead, it utilized the concept proposed by Van Ooijen et al. (2019), which presents a new perspective in terms of databased value creation in the context of the public sector and views data as a strategic resource that governments can also use to support evidence-based decision-making.

Third, this research examined the role of governments as potential users of data. This was in contrast to most literature, where application developers, entrepreneurs, researchers, journalists, non-profit organizations, and citizens in general are posited as potential users of OGD. (Lassinantti, 2019; Safarov et al., 2017). Governments can use data on practices and procedures to promote organizational change and extract knowledge to support government actions. Even policymakers already believe that OGD will be a resource for reforming public management and internal administrative processes (Kassen, 2020).

Fourth, the study contributed to the generalization of the diffusion of innovation theory and opens up opportunities for further research in public management by casting a new light on the adoption of a DDPS culture within governments. It is important to emphasize that the value creation of OGD does not assume that all governments will obtain the same opportunities, nor does it imply that one government uses OGD for other purposes.

Fifth, this study provided a measure to capture value creation from OGD, making it possible to accelerate studies on DDPS. For example, the measure would be useful to examine the organizational scenario, verify the favorable conditions for implementing DDPS culture, and identify potential challenges, since OGD is beginning to be recognized as a support tool for managers and public servants in their routines, activities, and processes (Van Ooijen et al., 2019). Finally, the measure is not only valid and reliable, but also parsimonious. It helps professionals assess different organizational and individual variables through a single instrument (e.g., Altayar, 2018; Huber et al., 2020; Saxena \& Janssen, 2017; Zuiderwijk et al., 2015).

\section{Conclusion}

This study provided a comprehensive scale that enables the identification of the factors involved in generating value from the use of OGD by the public sector. The results showed that the developed multidimensional scale meets all established criteria and serves as a sound measure. Its construction was based on sufficiently robust theoretical bases that provided a conceptual base with measures to evaluate and better understand the conditions of public organizations regarding the use of OGD.

The scale can serve as a scientific tool for researchers who wish to assess the antecedents of value generation resulting from OGD using an integrated view, which involves organizational adoption, 
behavioral intention, and absorptive capacity. It also offers new avenues for research on the use of OGD and the digital transformation of the public sector, especially driving new experiences in the DDPS.

The practical implications of this measure include the possibility of implementing it as a standardized government tool to compare the results of various departments and sectors, diagnose the real situation of public organizations regarding the intelligent use of data, and as support to establish strategies and actions and institutionalize or improve the use of data in routines, activities, processes, and decisions.

This study has certain limitations. Given that this study addresses an under explored subject and refers to the construction of a measure to capture the generation of value through the use of OGD, additional empirical research is required to substantiate its results. Although the scale is reliable and valid, the measure is new and complex. It thus requires further study to ensure its refinement. Another limiting factor is the study's limited sample. Given that only the perception of public servants in the federal sphere was inferred, and it is not possible to conclude that the measurement instrument can be applied in the same way in other spheres of government. Future research should thus replicate the instrument across different contexts, cultures, and levels of government (local, regional, and national) to test and further validate the scale.

\section{References}

Adnan, H. R., Hidayanto, A. N., Purwandari, B., Kosandi, M., Fitriani, W. R., \& Kurnia, S. (2019). Multidimensional perspective on factors influencing technology adoption for open government initiatives: A systematic literature review. 2019 International Conference on Advanced Computer Science and Information Systems, ICACSIS 2019, 369-374. https:/ / doi.org/10.1109/ICACSIS47736.2019.8979924

Agbozo, E., \& Asamoah, B. K. (2019). Data-driven e-government: Exploring the socio-economic ramifications. EJournal of EDemocracy and Open Government, 11(1), 81-90. https://doi.org/10.29379/jedem.v11i1.510

Akter, S., Fosso Wamba, S., \& Dewan, S. (2017). Why PLS-SEM is suitable for complex modelling? An empirical illustration in big data analytics quality. Production Planning and Control, 28(11-12), 1011-1021. https://doi.org/10.1080/09537287.2016.1267411

Ali, N., Tretiakov, A., \& Whiddett, D. (2014). A content validity study for a knowledge management systems success model in healthcare. Journal of Information Technology Theory and Application (JITTA), 15(2), 21. https://aisel.aisnet.org/jitta/vol15/iss2/3

Altayar, M. S. (2018). Motivations for open data adoption: An institutional theory perspective. Government Information Quarterly, 35(4), 633-643. https://doi.org/10.1016/j.giq.2018.09.006

Attard, J., Orlandi, F., \& Auer, S. (2016). Value creation on open government data. Proceedings of the Annual Hawaii International Conference on System Sciences, 2016-March, 2605-2614. https://doi.org/10.1109/HICSS.2016.326

Barney, J. (1991). Firm Resources and Sustained Competitive Advantage. Journal of Management, 17(1), 99120. https:// doi.org/10.1177/014920639101700108 
Berry, F. S., \& Berry, W. D. (1990). State Lottery Adoptions as Policy Innovations: An Event History Analysis. American Political Science Review, 84(2), 395-415. https:// doi.org/10.2307/1963526

Brasil. (2020, November 13). Fala.BR - Integrated Ombudsman and Access to Information Platform. https://falabr.cgu.gov.br/publico/Manifestacao/SelecionarTipoManifestacao.aspx?ReturnUrl=\%2F

Brasil. (2021). Law No. 14,129 of March 29, 2021. Provides for principles, rules and instruments for Digital Government and for increasing public efficiency.

https://legislacao.presidencia.gov.br/atos/?tipo=LEI\&numero=14129\&ano=2021\&ato=d7cMTSE5UM ZpWT475

Churchill, G. A. (1979). A Paradigm for Developing Better Measures of Marketing Constructs. Journal of Marketing Research, 16(1), 64-73. https://doi.org/10.1177/002224377901600110

Cohen, W. M., \& Levinthal, D. A. (1990). Absorptive Capacity: A New Perspective on Learning and Innovation. Administrative Science Quarterly, 35(1), 128. https:/ / doi.org/10.2307/2393553

Damanpour, F. (1991). Organizational Innovation: A Meta-Analysis Of Effects Of Determinants and Moderators. Academy of Management Journal, 34(3), 555-590. https:/ / doi.org/10.5465/256406

Dawes, S. S., Vidiasova, L., \& Parkhimovich, O. (2016). Planning and designing open government data programs: An ecosystem approach. Government Information Quarterly, 33(1), 15-27. https://doi.org/10.1016/J.GIQ.2016.01.003

del Carmen Haro-Domínguez, M., Arias-Aranda, D., Javier Lloréns-Montes, F., \& Ruíz Moreno, A. (2007). The impact of absorptive capacity on technological acquisitions engineering consulting companies. Technovation, 27(8), 417-425. https://doi.org/10.1016/j.technovation.2007.04.003

Dimaggio, P. J., \& Powell, W. W. (1983). The iron cage revisited: institutional isomorphism and collective rationality in organizational fields. American Sociological Review, 48(2), 147-160. https:/ / doi.org/DOI: $10.2307 / 2095101$

Duan, H. K., Hu, H., Vasarhelyi, M., Rosa, F. S., \& Leão Lyrio, M. V. (2020). Open Government Data (OGD) driven decision aid: a predictive model to monitor COVID-19 and support decisions in a Brazilian State. Public Service Magazine, 71, 140-164. https://doi.org/10.21874/rsp.v71i0.5009

Dwivedi, Y. K., Rana, N. P., Jeyaraj, A., Clement, M., \& Williams, M. D. (2019). Re-examining the Unified Theory of Acceptance and Use of Technology (UTAUT): Towards a Revised Theoretical Model. Information Systems Frontiers, 21(3), 719-734. https://doi.org/10.1007/s10796-017-9774-y

Finstad, K. (2010). Response interpolation and scale sensitivity: Evidence against 5-point scales. Journal of Usability Studies, 5(3), 104-110.

Flatten, T. C., Engelen, A., Zahra, S. A., \& Brettel, M. (2011). A measure of absorptive capacity: Scale development and validation. European Management Journal, 29(2), 98-116. https://doi.org/10.1016/J.EMJ.2010.11.002

Floyd, F. J., \& Widaman, K. F. (1995). Factor Analysis in the Development and Refinement of Clinical Assessment Instruments. Psychological Assessment, 7(3), 286-299. 
Fornell, C., \& Larcker, D. F. (1981). Evaluating Structural Equation Models with Unobservable Variables and Measurement Error. Journal of Marketing Research, 18(1), 39-50. https://doi.org/10.1177/002224378101800104

Gao, X., \& Yu, J. (2020). Public governance mechanism in the prevention and control of the COVID-19: information, decision-making and execution. Journal of Chinese Governance, 5(2), 178-197. https://doi.org/10.1080/23812346.2020.1744922

Gefen, D., \& Straub, D. (2005). A Practical Guide to Factorial Validity Using PLS-Graph: Tutorial and Annotated Example. Communications of the Association for Information Systems, 16, 91-109. http://dstraub.cis.gsu.edu:88/quant/

Grimmelikhuijsen, S. G., \& Feeney, M. K. (2017). Developing and Testing an Integrative Framework for Open Government Adoption in Local Governments. Public Administration Review, 77(4), 579-590. https://doi.org/10.1111/puar.12689

Guo, L., \& Ba, Y. (2019). Adopt or Not and Innovation Variation: A Dynamic Comparison Study of Policy Innovation and Diffusion Mechanisms. Journal of Comparative Policy Analysis: Research and Practice. https://doi.org/10.1080/13876988.2019.1603603

Hair, J. F., Black, W. C., Babin, B. J., \& Anderson, R. E. (2019). Multivariate Data Analysis (8th Editio). Cengage Learning.

Hair, J. J. F., Black, W. C., \& Sant'Anna, A. S. (2009). Multivariate data analysis. Bookman Publisher.

Hair, Joe F., Howard, M. C., \& Nitzl, C. (2020). Assessing measurement model quality in PLS-SEM using confirmatory composite analysis. Journal of Business Research, 109, 101-110.

https://doi.org/10.1016/j.jbusres.2019.11.069

Hair, Joe F., Ringle, C. M., \& Sarstedt, M. (2011). PLS-SEM: Indeed a silver bullet. Journal of Marketing Theory and Practice, 19(2), 139-152. https:/ / doi.org/10.2753/MTP1069-6679190202

Haneem, F., Kama, N., Taskin, N., Pauleen, D., \& Abu Bakar, N. A. (2019). Determinants of master data management adoption by local government organizations: An empirical study. International Journal of Information Management, 45, 25-43. https://doi.org/10.1016/j.ijinfomgt.2018.10.007

Henseler, J., Ringle, C. M., \& Sarstedt, M. (2015). A new criterion for assessing discriminant validity in variance-based structural equation modeling. Journal of the Academy of Marketing Science, 43(1), 115-135. https://doi.org/10.1007/s11747-014-0403-8

Hinkin, T. R. (1998). A brief tutorial on the development of measures for use in survey questionnaires. Organizational Research Methods, 1(1), 104-121. https:/ / doi.org/10.1177/109442819800100106

Huber, F., Wainwright, T., \& Rentocchini, F. (2020). Open data for open innovation: managing absorptive capacity in SMEs. R\&D Management, 50(1), 31-46. https:/ / doi.org/10.1111/radm.12347

Jetzek, T., Avital, M., \& Bjorn-Andersen, N. (2014). Data-Driven Innovation through Open Government Data. Journal of Theoretical and Applied Electronic Commerce Research, 9(2), 15-16. https://doi.org/10.4067/S0718-18762014000200008

Jetzek, T., Avital, M., \& Bjørn-Andersen, N. (2013a). Generating Value from Open Government Data. 34th International Conference on Information Systems, 1-20. 
Jetzek, T., Avital, M., \& Bjørn-Andersen, N. (2013b). The Generative Mechanisms Of Open Government Data. In 1 (Ed.), Proceedings of the 21st European Conference on Information Systems (Vol. 156).

Joshi, A., Kale, S., Chandel, S., \& Applied, D. (2015). Likert scale: Explored and explained. British Journal of Applied Science \& Technology, 7(4), 396-403. https:/ / doi.org/10.9734/BJAST/2015/14975

Kaiser, H. F. (1960). The Application of Electronic Computers to Factor Analysis. Educational and Psychological Measurement, 20(1), 141-151. https:// doi.org/10.1177/001316446002000116

Kassen, M. (2020). Open data and its peers: understanding promising harbingers from Nordic Europe. Aslib Journal of Information Management. https:/ / doi.org/10.1108/ AJIM-12-2019-0364

Kim, S., Kim, H. J., \& Lee, H. (2009). An institutional analysis of an e-government system for anti-corruption: The case of OPEN. Government Information Quarterly, 26(1), 42-50.

https://doi.org/10.1016/j.giq.2008.09.002

Lane, P. J., Koka, B. R., \& Pathak, S. (2006). The reification of absorptive capacity: A critical review and rejuvenation of the construct. Academy of Management Review, 31(4), 833-863. https://doi.org/10.5465/AMR.2006.22527456

Lassinantti, J. (2019). Re-use of public sector open data-charcterising the phenomena. International Journal of Public Information Systems, 13(1), 1-29.

Lee, G., \& Kwak, Y. H. (2012). An Open Government Maturity Model for social media-based public engagement. Government Information Quarterly, 29(4), 492-503.

https://doi.org/10.1016/J.GIQ.2012.06.001

Lewin, A. Y., Massini, S., \& Peeters, C. (2011). Microfoundations of internal and external absorptive capacity routines. Organization Science, 22(1), 81-98. https://doi.org/10.1287/orsc.1100.0525

MacKenzie, S. B., Podsakoff, P. M., \& Podsakoff, N. P. (2011). Construct measurement and validation procedures in MIS and behavioral research: Integrating new and existing techniques. MIS Quarterly, 35(2), 293-334.

Maffei, S., Leoni, F., \& Villari, B. (2020). Data-driven anticipatory governance. Emerging scenarios in data for policy practices . Policy Design and Practice, 3(2), 123-134.

https://doi.org/10.1080/25741292.2020.1763896

McBride, K., Aavik, G., Toots, M., Kalvet, T., \& Krimmer, R. (2019). How does open government data driven co-creation occur? Six factors and a 'perfect storm'; insights from Chicago's food inspection forecasting model. Government Information Quarterly, 36(1), 88-97. https://doi.org/10.1016/j.giq.2018.11.006

Mergel, I., Kleibrink, A., \& Sörvik, J. (2018). Open data outcomes: U.S. cities between product and process innovation. Government Information Quarterly, 35(4), 622-632. https://doi.org/10.1016/j.giq.2018.09.004

Murray, K., Roux, D. J., Nel, J. L., Driver, A., \& Freimund, W. (2011). Absorptive Capacity as a Guiding Concept for Effective Public Sector Management and Conservation of Freshwater Ecosystems. Environmental Management, 47(5), 917-925. https://doi.org/10.1007/s00267-011-9659-7

Nunnally, J. (1978). Psychometric theory. McGraW-Hill. 
OECD. (2020). 12 Principles - Organisation for Economic Co-operation and Development. https://www.oecd.org/governance/digital-government/toolkit/12principles/

Pestana, M. H., \& Gageiro, J. G. (2008). Data analysis for social sciences: the complementarity of SPSS (5th ed.). Sílabo.

Premkumar, G., \& Roberts, M. (1999). Adoption of new information technologies in rural small businesses. Omega, 27(4), 467-484. https://doi.org/10.1016/S0305-0483(98)00071-1

Rogers, E. M. (1995). Diffusion of innovations (4th ed.). Free Press.

Ruijer, E., \& Meijer, A. (2019). Open Government Data as an Innovation Process: Lessons from a Living Lab Experiment. Public Performance \& Management Review, 1-23. https://doi.org/10.1080/15309576.2019.1568884

Safarov, I., Meijer, A., \& Grimmelikhuijsen, S. (2017). Utilization of open government data: A systematic literature review of types, conditions, effects and users. Information Polity, 22(1), 1-24. https://doi.org/10.3233/IP-160012

Saxena, S., \& Janssen, M. (2017). Examining open government data (OGD) usage in India through UTAUT framework. Foresight, 19(4), 421-436. https://doi.org/10.1108/FS-02-2017-0003

Scott, W. R. (2013). Institutions and organizations: Ideas, interests, and identities. Sage publications.

Sivarajah, U., Weerakkody, V., Waller, P., Lee, H., Irani, Z., Choi, Y., Morgan, R., \& Glikman, Y. (2016). The role of e-participation and open data in evidence-based policy decision making in local government. Journal of Organizational Computing and Electronic Commerce, 26(1-2), 64-79. https://doi.org/10.1080/10919392.2015.1125171

Szulanski, G. (1996). Exploring internal stickiness: Impediments to the transfer of best practice within the firm. Strategic Management Journal, 17(S2), 27-43. https://doi.org/10.1002/smj.4250171105

Todorova, G., \& Durisin, B. (2005). The Concept and the Reconceptualization of Absorptive Capacity: Recognizing the Value. SSRN Electronic Journal. https://doi.org/10.2139/ssrn.457520

Todorova, G., \& Durisin, B. (2007). Absorptive capacity: Valuing a reconceptualization. Academy of Management Review, 32(3), 774-786. https://doi.org/10.5465/amr.2007.25275513

Tornatzky, L., Fleischer, M., \& Chakrabarti, A. (1990). Processes of technological innovation. Lexington books.

Ubaldi, B. (2020). The OECD Digital Government Policy Framework: Six dimensions of a Digital Government. https://doi.org/10.1787/f64fed2a-en

Van Ooijen, C., Ubaldi, B., \& Welby, B. (2019). A data-driven public sector: Enabling the strategic use of data for productive, inclusive and trustworthy governance. In OECD Working Papers on Public Governance (Issue 33). https://doi.org/10.1787/09ab162c-en

Venkatesh, V., Morris, M., Davis, G., \& Davis, F. (2003). User Acceptance of Information Technology: Toward a Unified View. Management Information Systems Quarterly, 27(3).

https:// doi.org/10.2307/30036540 
Wang, H. J., \& Lo, J. (2016). Adoption of open government data among government agencies. Government Information Quarterly, 33(1), 80-88. https://doi.org/10.1016/J.GIQ.2015.11.004

Welch, E. W., Feeney, M. K., \& Park, C. H. (2016). Determinants of data sharing in U.S. city governments. Government Information Quarterly, 33(3), 393-403. https://doi.org/10.1016/j.giq.2016.07.002

Williams, M. D., Rana, N. P., \& Dwivedi, Y. K. (2015). The unified theory of acceptance and use of technology (UTAUT): A literature review. Journal of Enterprise Information Management, 28(3), 443-448. https://doi.org/10.1108/JEIM-09-2014-0088

Yang, T. M., \& Wu, Y. J. (2016). Examining the socio-technical determinants influencing government agencies' open data publication: A study in Taiwan. Government Information Quarterly, 33(3), 378-392. https://doi.org/10.1016/j.giq.2016.05.003

Yavuz, N., \& Welch, E. W. (2014). Factors affecting openness of local government websites: Examining the differences across planning, finance and police departments. Government Information Quarterly, 31(4), 574-583. https://doi.org/10.1016/j.giq.2014.07.004

Zahra, S. A., \& George, G. (2002). Absorptive Capacity: A Review, Reconceptualization, and Extension. Academy of Management Review, 27(2), 185-203. https:/ / doi.org/10.5465/amr.2002.6587995

Zhao, Y., \& Fan, B. (2018). Exploring open government data capacity of government agency: Based on the resource-based theory. Government Information Quarterly, 35(1), 1-12. https://doi.org/10.1016/j.giq.2018.01.002

Zuiderwijk, A., Janssen, M., \& Dwivedi, Y. K. (2015). Acceptance and use predictors of open data technologies: Drawing upon the unified theory of acceptance and use of technology. Government Information Quarterly, 32(4), 429-440. https://doi.org/10.1016/j.giq.2015.09.005

\section{About the Authors}

\section{Vanessa Oliveira}

Vanessa Hernandes Oliveira is Ph.D. student in the Management Department at University of Beira Interior, Portugal. She is currently a researcher of NECE-UBI - Research Centre for Business Sciences. Her main research areas are open government, public management, digital government. She has articles published in congress and one book chapter. E-mail: vanessa.hernandes.oliveira@ubi.pt; https://orcid.org/0000-00023228-3899

\section{DR. Paulo Pinheiro}

Paulo Gonçalves Pinheiro is a Full Professor at the University of Beira Interior (UBI), Department of Economics and Business, and a researcher at NECE, Center for Research in Business Sciences (UBI). His teaching activities are mainly on knowledge management and comprehend undergraduate, master, and doctoral students. He is a Ph.D. in administration and the author of several publications. His main research areas are knowledge management, organizational wisdom, organizational spirituality, management theory, information management. E-mail: pgp@ubi.pt; https://orcid.org/0000-0003-2397-6463 


\section{DR. Nelson Pinto}

Nelson Guilherme Machado Pinto is an adjunct professor at the Administration Department at the Federal University of Santa Maria (UFSM), Palmeira das Missões campus - RS, Ph.D. in Administration at the Federal University of Santa Maria (PPGA / UFSM), master's in administration at PPGA / UFSM and bachelor's degree in Administration from the Federal University of Santa Maria (UFSM), Santa Maria, RS, Brazil. His main research areas are public governance, public finance, public transparency, default, credit management, efficiency analysis, regional development, and the socioeconomic impacts of covid-19. He is the author of several publications. E-mail: nelguimachado@hotmail.com; https://orcid.org/0000-0003-1105-2271

\section{Appendix}

Measurement items

\begin{tabular}{|c|c|c|}
\hline $\begin{array}{l}\text { Constructs/ } \\
\text { latent variables }\end{array}$ & Items & Authors \\
\hline \multicolumn{3}{|c|}{ ORGANIZATIONAL FACTORS } \\
\hline \multirow{3}{*}{ 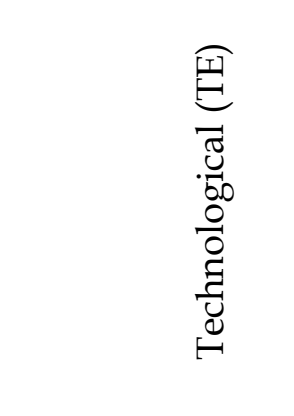 } & $\begin{array}{l}\text { TE_1) Our organization is well equipped to } \\
\text { manage important security and privacy issues } \\
\text { regarding the adoption of OGD. }\end{array}$ & $\begin{array}{l}\text { Yavuz and Welch } \\
\text { (2014) }\end{array}$ \\
\hline & $\begin{array}{l}\text { TE_2) Our organization has adopted clear data } \\
\text { security policies to ensure citizen privacy. }\end{array}$ & Welch et al. (2016) \\
\hline & $\begin{array}{l}\text { TE_3) Our IT people have knowledge, skills, } \\
\text { and experience. }\end{array}$ & $\begin{array}{l}\text { Haneem et al. } \\
(2019)\end{array}$ \\
\hline \multirow{6}{*}{ 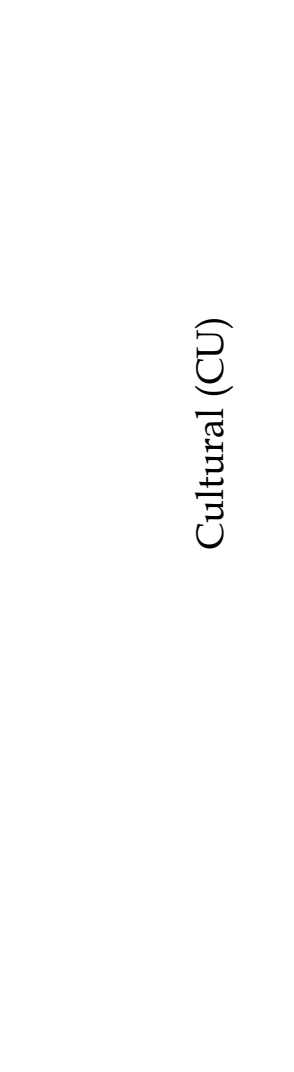 } & $\begin{array}{l}\text { CU_1) Our organization has a strong commit- } \\
\text { ment to innovation. People who develop inno- } \\
\text { vative solutions to problems are recognized. }\end{array}$ & \multirow{6}{*}{$\begin{array}{l}\text { Grimmelikhuijsen } \\
\text { and Feeney (2017) }\end{array}$} \\
\hline & $\begin{array}{l}\text { CU_2) Our organization is a very dynamic and } \\
\text { entrepreneurial place. People are willing to take } \\
\text { risks. }\end{array}$ & \\
\hline & $\begin{array}{l}\text { CU_3) Our managers have attitudes favorable } \\
\text { to change (guidance, support, and support). In } \\
\text { the case of the use of OGD, they drive the crea- } \\
\text { tion of new electronic services and mobile ap- } \\
\text { plications. }\end{array}$ & \\
\hline & $\begin{array}{l}\text { CU_4) Our organization believes that citizen } \\
\text { participation, especially in deliberative and de- } \\
\text { cision-making processes, is necessary. }\end{array}$ & \\
\hline & $\begin{array}{l}\text { CU_5) Our organization believes that citizen } \\
\text { participation increases the effectiveness of pub- } \\
\text { lic administration. }\end{array}$ & \\
\hline & $\begin{array}{l}\text { CU_6) Our organization believes that it is the } \\
\text { responsibility of the public administration to }\end{array}$ & \\
\hline
\end{tabular}




\begin{tabular}{|c|c|c|}
\hline & $\begin{array}{l}\text { encourage citizens to participate in the deliber- } \\
\text { ation and decision-making processes. }\end{array}$ & \\
\hline \multirow{9}{*}{ 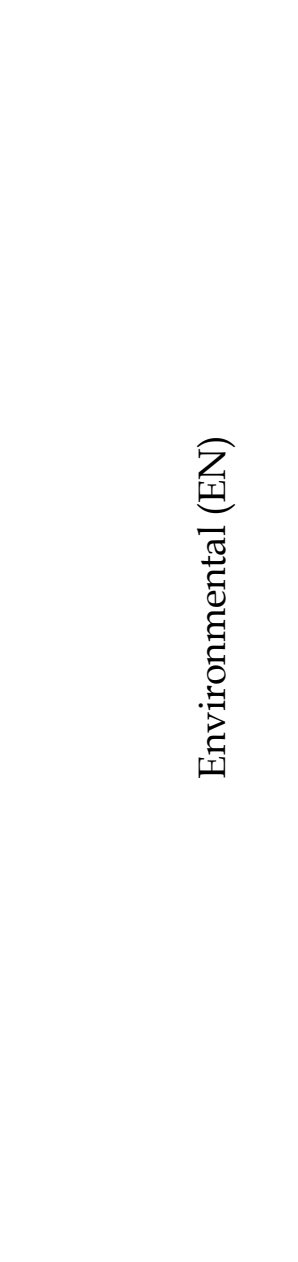 } & $\begin{array}{l}\text { EN_1) The other public organizations have } \\
\text { placed a lot of emphasis on the adoption of } \\
\text { OGD. * }\end{array}$ & $\begin{array}{l}\text { Wang and Lo } \\
(2016)\end{array}$ \\
\hline & $\begin{array}{l}\text { EN_2) Most public organizations have adopted } \\
\text { OGD in their procedures. }\end{array}$ & \multirow[t]{2}{*}{ Altayar (2018) } \\
\hline & $\begin{array}{l}\text { EN_3) Public organizations that used OGD had } \\
\text { benefits. * }\end{array}$ & \\
\hline & $\begin{array}{l}\text { EN_4) Higher-level public bodies place a lot of } \\
\text { emphasis on the adoption of OGD. }\end{array}$ & $\begin{array}{l}\text { Wang and Lo } \\
(2016)\end{array}$ \\
\hline & $\begin{array}{l}\text { EN_5) Our body adopted specific organiza- } \\
\text { tional practices after the publication of poli- } \\
\text { cies/legislation on OGD. * }\end{array}$ & $\begin{array}{l}\text { Grimmelikhuijsen } \\
\text { and Feeney (2017); } \\
\text { Wang and Lo } \\
\text { (2016) }\end{array}$ \\
\hline & $\begin{array}{l}\text { EN_6) OGD was widely adopted by federal } \\
\text { public agencies. }\end{array}$ & \multirow{4}{*}{$\begin{array}{l}\text { Altaya (2018); } \\
\text { Grimmelikhuijsen } \\
\text { and Feeney (2017); } \\
\text { Kim et al. (2009) }\end{array}$} \\
\hline & EN_7) OGD was adopted by society. & \\
\hline & $\begin{array}{l}\text { EN_8) OGD has been widely adopted by non- } \\
\text { governmental and private organizations. }\end{array}$ & \\
\hline & $\begin{array}{l}\text { EN_9) There is internal pressure, by parts of the } \\
\text { servers that adopt OGD, in their professional } \\
\text { area.* }\end{array}$ & \\
\hline \multicolumn{3}{|c|}{ INDIVIDUAL FACTORS } \\
\hline \multirow{4}{*}{ 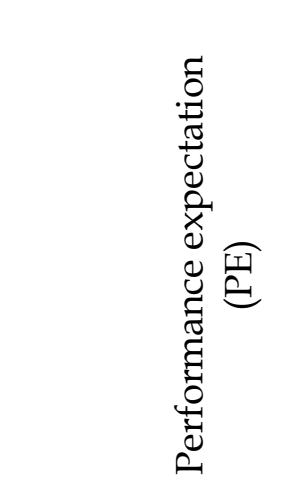 } & $\begin{array}{l}\text { PE_1) The use of OGD is beneficial for my pro- } \\
\text { fessional performance. }\end{array}$ & \multirow{7}{*}{$\begin{array}{l}\text { Venkatesh et al. } \\
\text { (2003); Zuiderwijk } \\
\text { et al. (2015) }\end{array}$} \\
\hline & $\begin{array}{l}\text { PE_2) The use of OGD will be useful in my daily } \\
\text { activities at work. }\end{array}$ & \\
\hline & $\begin{array}{l}\text { PE_3) The use of OGD will increase my produc- } \\
\text { tivity. }\end{array}$ & \\
\hline & $\begin{array}{l}\text { PE_4) Using OGD will improve my perfor- } \\
\text { mance at work. }\end{array}$ & \\
\hline \multirow{3}{*}{ 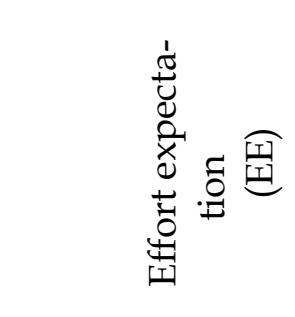 } & $\begin{array}{l}\text { EE_1) I can easily develop the skills required to } \\
\text { use OGD. }\end{array}$ & \\
\hline & $\begin{array}{l}\text { EE_2) Learning how to use OGD will be easy for } \\
\text { me. }\end{array}$ & \\
\hline & EE_3) I totally understand how OGD works. & \\
\hline
\end{tabular}




\begin{tabular}{|l|l|}
\hline & $\begin{array}{l}\text { EE-4) I have no difficulty in explaining why the } \\
\text { use of OGD can be beneficial in my professional } \\
\text { life. }\end{array}$ \\
\hline & $\begin{array}{l}\text { SI_1) People who influence my professional be- } \\
\text { havior think I should use OGD. }\end{array}$ \\
\cline { 1 - 2 } & $\begin{array}{l}\text { SI_2) People who are important to me think I } \\
\text { should use OGD. }\end{array}$ \\
\cline { 1 - 2 } & $\begin{array}{l}\text { SI_3) People whose opinions I value encourage } \\
\text { the use of OGD. }\end{array}$ \\
\hline
\end{tabular}

\section{FACILITATING FACTOR}

\begin{tabular}{|c|c|c|}
\hline \multirow{10}{*}{ 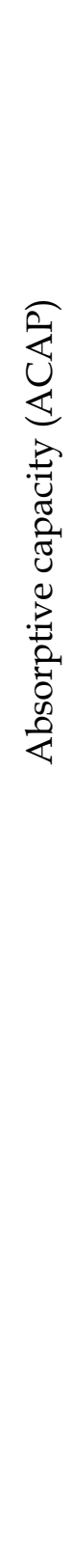 } & $\begin{array}{l}\text { ACAP_1) The search for relevant information } \\
\text { about our industry is a daily activity in our or- } \\
\text { ganization. * }\end{array}$ & \multirow{10}{*}{ Flatten et al. (2011) } \\
\hline & $\begin{array}{l}\text { ACAP_2) Our managers motivate servers to use } \\
\text { sources of information regarding the area of ac- } \\
\text { tivity of your organization. }\end{array}$ & \\
\hline & $\begin{array}{l}\text { ACAP_3) Our organization expects servers to } \\
\text { handle information beyond their industry. }{ }^{*}\end{array}$ & \\
\hline & $\begin{array}{l}\text { ACAP_4) In our organization, ideas and con- } \\
\text { cepts are communicated across sectors. }\end{array}$ & \\
\hline & $\begin{array}{l}\text { ACAP_5) Our organization emphasizes collab- } \\
\text { oration across sectors to solve problems. }\end{array}$ & \\
\hline & $\begin{array}{l}\text { ACAP_6) In our organization, there is a rapid } \\
\text { flow of information; for example, if one } \\
\text { unit/sector obtains important information, it } \\
\text { communicates that information immediately to } \\
\text { all other units/sectors/departments. }\end{array}$ & \\
\hline & $\begin{array}{l}\text { ACAP_7) Our administration requires periodic } \\
\text { intersectoral meetings to exchange new devel- } \\
\text { opments, problems, and achievements. }\end{array}$ & \\
\hline & $\begin{array}{l}\text { ACAP_8) Our organization aggregates data } \\
\text { provided by citizens/users to improve service } \\
\text { delivery. }\end{array}$ & \\
\hline & $\begin{array}{l}\text { ACAP_9) Our servers are empowered to absorb } \\
\text { new knowledge, use it for other purposes and } \\
\text { make it available. }\end{array}$ & \\
\hline & $\begin{array}{l}\text { ACAP_10) Our servers associate existing } \\
\text { knowledge with new solutions. * }\end{array}$ & \\
\hline
\end{tabular}




\begin{tabular}{|c|c|c|}
\hline & $\begin{array}{l}\text { ACAP_11) Our servers are able to apply new } \\
\text { knowledge in their practical work. }\end{array}$ & \\
\hline & $\begin{array}{l}\text { ACAP_12) Our organization supports systems } \\
\text { development. }\end{array}$ & \\
\hline & $\begin{array}{l}\text { ACAP_13) Our organization regularly recon- } \\
\text { siders technologies and adapts them according } \\
\text { to new knowledge. }\end{array}$ & \\
\hline & $\begin{array}{l}\text { ACAP_14) Our organization manages to work } \\
\text { effectively and adopts new technologies. }\end{array}$ & \\
\hline VALUE GEN & & \\
\hline & $\begin{array}{l}\text { VGE_1) In our organization, OGD are used as } \\
\text { support to guide our governance efforts when } \\
\text { considering the future in decision making. }\end{array}$ & \\
\hline & $\begin{array}{l}\text { VGE_2) Our organization uses OGD and trends } \\
\text { to try to predict the results of our management } \\
\text { actions. }\end{array}$ & \\
\hline 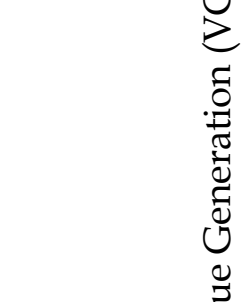 & $\begin{array}{l}\text { VGE_3) Our organization systematically ex- } \\
\text { plores several plausible versions of how the fu- } \\
\text { ture might be different than expected and then } \\
\text { uses them to make our decisions more prepared } \\
\text { and agile today. For this, analysis based on } \\
\text { open data is used. }\end{array}$ & \\
\hline$\rho^{\pi}$ & $\begin{array}{l}\text { VGE_4) Our servers are encouraged to use } \\
\text { OGD to develop evidence-based actions. }\end{array}$ & \\
\hline & $\begin{array}{l}\text { VGE_5) Our managers use OGD to support the } \\
\text { debate process with stakeholders by providing } \\
\text { detailed information on a political problem in } \\
\text { an accessible way. }\end{array}$ & \\
\hline & $\begin{array}{l}\text { VGE_6) Our organization analyzes data about } \\
\text { citizens/users' opinions and/or behaviors to } \\
\text { create more robust, evidence-based policies. }\end{array}$ & $\begin{array}{l}\text { Van Ooijen et al. } \\
\text { (2019) }\end{array}$ \\
\hline & $\begin{array}{l}\text { VGE_7) Our organization uses data from other } \\
\text { public institutions to improve service delivery. }\end{array}$ & \\
\hline & $\begin{array}{l}\text { VGE_8) Our organization aggregates the data } \\
\text { provided by citizens/users to improve the pro- } \\
\text { vision of services. }\end{array}$ & \\
\hline & $\begin{array}{l}\text { VGE_9) Our managers incorporate data analyt- } \\
\text { ics into their processes in an attempt to reduce } \\
\text { operating costs. }\end{array}$ & \\
\hline
\end{tabular}




\begin{tabular}{|l|l|}
\hline & $\begin{array}{l}\text { VGE_10) Managers adopt relevant OGD in the } \\
\text { planning and implementation of financial, ma- } \\
\text { terial, and human resources to improve the effi- } \\
\text { ciency of the public organization. }\end{array}$ \\
\cline { 1 - 2 } & $\begin{array}{l}\text { VGE_11) Our organization analyzes the OGD to } \\
\text { identify the effects of a policy decision or action } \\
\text { and then makes the necessary adjustments. }\end{array}$ \\
\cline { 1 - 2 } & $\begin{array}{l}\text { VGE_12) Our organization does OGD-based } \\
\text { performance monitoring. }\end{array}$ \\
\hline
\end{tabular}

Note: * Deleted item 